\title{
Sedimentological, Lithostratigraphic, Clayey and Exoscopic Study of the Senonian Series of Arg N'Sidi Ali Ou Bourk, High Central Atlas of Morocco
}

\author{
Abdelouhed Farah ${ }^{1} 8(D) \otimes$, Ahmed Algouti ${ }^{2}$ (D), Abdellah Algouti ${ }^{3}$ 8(D), Abdelhalim Tabit ${ }^{4}$ 8(D) . \\ Hadach Fatiha ${ }^{5}$ (D) and Zahra Mourabit 6 8 (D) \\ ${ }^{123456}$ University of Cadi Ayyad, Faculty of Sciences Semlalia, Department of Geology, Geoscience Geotourism Natural Hazards \\ and Remote Sensing Laboratory (2 GRNT), BP 2390, 40000, Marrakech, Morocco
}

$\triangle$ Corresponding Author: Abdelouhed Farah, E-mail: farah6faragh@gmail.com

\author{
ARTICLE INFORMATION \\ Received: March 08, 2021 \\ Accepted: April 14, 2021 \\ Volume: 2 \\ Issue: 1 \\ DOI: $10.32996 /$ jeas.2021.2.1.5
}

\section{KEYWORDS}

Sedimentology, Senonian series,

Paleogeography, High Central

Atlas of Morocco

\section{ABSTRACT}

The sedimentological study of the red formations (Senonian series) represents a challenge and an exciting subject that needs to be explored. This paper will present the sedimentological, stratigraphic, and paleogeographic aspects of the Upper Cretaceous of the ARG N'SIDIALI OR BOURK, Central High Atlas Morocco. In this region, a marker section was realized bed by bed and sampled in a very straightforward way in order to study stratigraphy, to describe, to interpret and to characterize the sedimentary environment of the senonian succession in the ARG N'SIDIALI OU BOURK region, more particularly the analysis of the clays by $X$-ray diffractometer (XRD) has allowed understanding the depositional environments of the Upper Cretaceous formations. Therefore, the Senonian of ARG N'SIDIALI OU BOURK corresponds to continental lagoon deposits. It is characterised by sedimentation in the continental environment (fluvial or flooded), with some rare marine ascents marked by the installation of whitish sandstone bars.

\section{Introduction}

The High Atlas is the masterpiece of the Atlasic domain (Michard,1976). It is a mountainous barrier much longer than it is wide: $800 \mathrm{Km}$ long and 40 to $80 \mathrm{Km}$ wide. It is elongated in an ENE-WSW direction and forms a typical example of an intracontinental chain located within the African plate (Mattauer et al.,1977; Cavallina et al ,2018). It is subdivided into three main parts. 1) Eastern High Atlas: The Eastern High Atlas is formed of the vast highland plateaus of the High Moulouya. These plateaus extend from Midelt province of Khenifra, sheltering the Jbel Ayachi (3747 meters) to Imilchil province of Errachidia, where the Jbel Saghro and the ancient massif of Tamlelt whose northern edge is occupied by its highest peaks, such as the Jbel Ayachi (3760 meters). 2) Central High Atlas: The Central High Atlas is an essentially limestone massif, morphologically dominated by tabular zones culminating at an altitude of 2,500 meters, which stretches from Azilal to Ouarzazate. The Jebel M'Goun (4071 meters) is the highest peak in this part of the High Atlas. 3) Western High Atlas: The Western High Atlas is the oldest massif, extends to the West, and below the central High Atlas from which the depression or corridor of Argana separates it; it is limited to the North by the parallel of Mogador, to the South by that of Agadir. From a stratigraphic point of view, the Senonian is a monotonous set of pink and red sands, more or less clayey, with beds of fibrous gypsum. These lagoon formations are $50 \mathrm{~m}$ to $100 \mathrm{~m}$ thick near the Jbel Saghro and $250 \mathrm{~m}$ to $300 \mathrm{~m}$ thick in the Imini basin. From the tectonic point of view, the Cenomanoturonian limestones were deposited during a relatively calm period. In contrast, the Senonian was a period of tectonic activity that led to the resumption of the subsidence of the basin, and the return to detrital sedimentation, linked to the overall uplift of this area which is already subject to erosion (Laville,1980) Associates the establishment of the Toundout water table with this event. The Upper Cretaceous outcrops follow the South- Atlasic Accident continuously from west to east. The Paleocene corresponds to a set of limestones and sandstones alternating with marls and showing a strong lateral variation of facies over short distances.

\section{K C AL-KINDI CENTER \\ R D FOR RESEARCH AND DEVELOPMENT}

Your gateway to world-class research

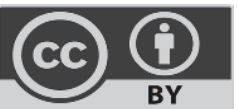

Published by Al-Kindi Center for Research and Development, London, United Kingdom. Copyright (c) the author(s). This open access article is distributed under a Creative Commons Attribution (CC-BY) 4.0 license 


\section{Methodology}

The sedimentological analysis of facies to determine the depositional media was carried out. In the field by recognising sedimentary structures and textures and, on the other hand, from the study of samples in macroscopy (polished surfaces). An exoscopic analysis for the quartz grains was made by a systematic prospecting of the relief of the grains (Quartz in the studied case), aiming at the identification of the phenomenorphic (PhM) characters and their localization (Marcelino, et al ,1999). A PhM is made up of all characters that will appear on the surface of the grain after the formation of the mother rock at the place of origin, during transport, during immobilization phases and finally during deposition. It appears very interesting to prospect for the clayey side in these reddish formations of the Upper Cretaceous because the evolution of clayey and non-clayey assemblages in this Central High Atlas Basin will depend mainly on the conjugation of tectonic (subsidence), eustatic, climatic and other influences. The principle of quartz exoscopy is simple: each natural environment is characterized by a set of factors of various origins: physical (pressure, temperature etc.), chemical (e.g.: concentration of dissolved silica in water, presence of iron hydroxides etc.), mechanical (e.g., wind or underwater shocks, friction, grinding phenomena, etc.), biological ( bacteria, diatoms, etc.), which leave on the surface of quartz grains traces of various shapes and sizes characteristic of the factors that generated them. When the grains pass from one environment to another, these traces are exploited in a specific way according to the characteristics of the factors that generated them. The analysis of these factors may soon determine the environments of the deposits of these clays and thus of the reddish formations in question.

\section{Geographical and geological setting}

This study is carried out in the Upper Cretaceous of ARG N'SIDIALI OU BOURK, Central High Atlas of Morocco (Figure.1). A group of very characteristic lithologies represents the Cretaceous in the High Atlas (Michard,1976), red sandstones and base conglomerates in continuity with Jurassic earth materials (traditionally called "infracanomanian" because of its difficulty in being dated). White limestones and dolomites of the Upper Cenomanian - Turonian age and (c) formation of red shales, with some sandstone and gypsum levels, attributed to the Senonians. The Pretectonic Paleogene is represented by alternating levels of bluish marls and bioclastic limestones that form the main reliefs of the Sub- Atlasic Zone and whose age is closer to Maastrichtian than to the Middle Lutetian (Marzoqi et al,2000; Tabuce et al ,2005)

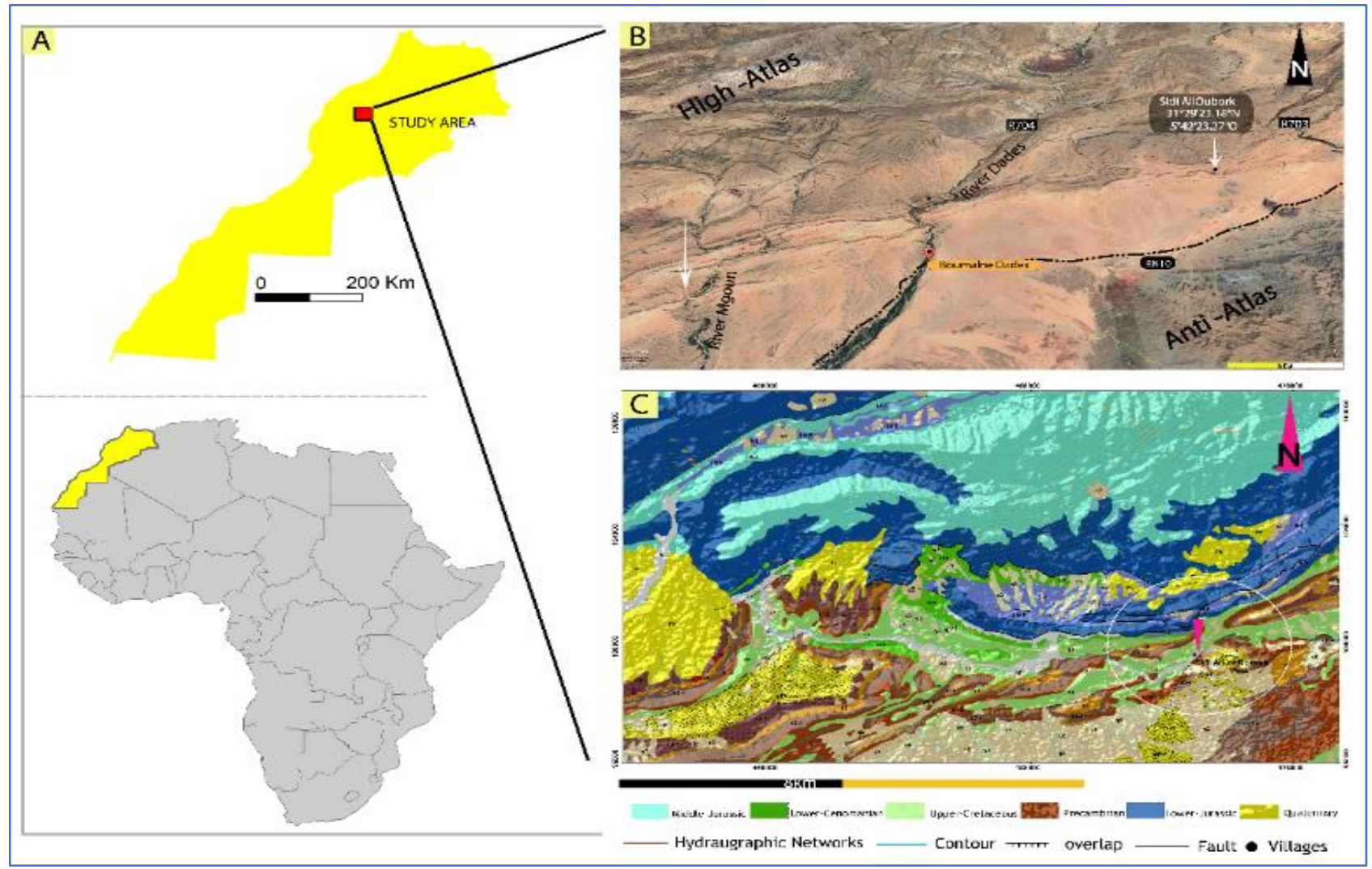

Figure.1 (A) geographical location of sector on map of Morocco, (B) satellite image of the studied area, reporting the Jurassic Upper Cretaceous units outcropping in the study basin, (C) simplified geological map (Jbel Saghrou Dade's 1/200,000. modified) (C) of the central High Atlas study area, showing the different geological formations making up the study area.

\section{Results and discussion}


The section shows at the base a carbonate cornice represented by $3 \mathrm{~m}$ thick limestone deposits that end in a fossil condensation surface (lamellibranches, gastropods, oysters). Then, we have the Senonian formed by an alternation of clay and red siltit of evaporitic appearance, sandstone with to kerokans, with traces of roots and desiccation slits), sometimes showing stromatolites (Figure.2). Carbonate deposits of the Paleocene surmount this. The raised section at ARG N'SIDI ALI OU BOURK shows several sedimentary figures useful in determining the deposit's environment. All lithological and paleoenvironmental data show an increase in hydrodynamic energy from the bottom to the top of the series, proven by the associated sedimentary figures (channel fillings, crossbedding, oblique and tangent bedding) and by the appearance of erosive bases.

\subsection{Sedimentary Figures}

Oblique bedding: Most oblique-bedded beams are indicators of flow direction and direction. They are related to the lateral migration of sandy wrinkles. Wave wrinkle cross-laminate (="waveripplestrata"). There are two cases, for oblique and crisscrossed beddings: Normal case (no displacement and deformation): The direction of transport will be either from the lover to the downstream (we measure the direction and direction of the sheets) for the oblique flat bedding, or measured at the bottom of the surface in gutters for the crossed bedding, Case of displacement and deformation: the posterior deformations of deposit, incline the bedding. As in the first case, the direction and inclination of each oblique sheet are measured, then, after measuring the direction and inclination of the beds, the whole is restored to its original (horizontal) position using the wulf canvas in stereographic projection on the poles of the sheets (Durand,1978). Channels: Studies for reconstructing the direction of paleocurrents in channels consist of measuring the channel axes' orientation.

Thalassinoides characterize tropical environments at shallow depths (Michard,1976; Weimer,1964). The type of burrows encountered at the base of this sequence are monotypic with a single tube of centimetric diameter and pluricentimetric length, attributed to the ichnogen Thalassinoides. These branches are arranged in a horizontal (hexagonal planar pattern), oblique or vertical burrow network, with widenings at the junctions of the branches, in the shape of a T or Y (Frey, 1978). The responsible organisms would support variable oxygenation conditions but never live in oxygen-poor environments (Ekdale et al ,2003; Colmenero-hidalgo et al ,2004). Moreover, (Kennedy et al,1969) shown that the maximum development of Thalassinoid burrows is in coastal environments (Bernier, 1984; Weimer et al,1964).

Bioturbation: is defined as all the disturbances induced by the activity of organisms living on the surface (epibenthic) and in the superficial sediment (benthic) (Rhoads et al,1974)

Kerkoubs: (from the Arabic verb kerkab to ball). These are indurated concretions of variable size (5 to $10 \mathrm{~mm}$ ), more or less spherical, disseminated or grouped in given horizons within sandstones. The presence of kerkoubs also testifies to a warm and semi-arid climate (Hadach et al 2015)

The presence of dissolution holes attests to a vadose diagenesis in an intertidal zone. The presence of dissolution attests to a superior intertidal environment.

Ripples marks: result from the action of a unidirectional current, are found in all environments (river or sea) and at all depths.

Asymmetrical ripples: the action of a unidirectional current creates these at relatively low speed (Reineck et al,2012).

Tipis: "chevron-shaped wrinkles (Le ribault,1977; Renaud-mornant et al1976), these are structures similar to symmetrical folds in the form of a circumflex accent, these structures appear within the calcareous facies, the interstitial growth of aragonite in marine or coastal environments was the probable cause of the expansion of sediments. These structures are also known in a warm semi-arid climate with desiccation reflecting a momentary emersion (High intertidal to supratidal zone). (Figure.3 and Figure 4) 


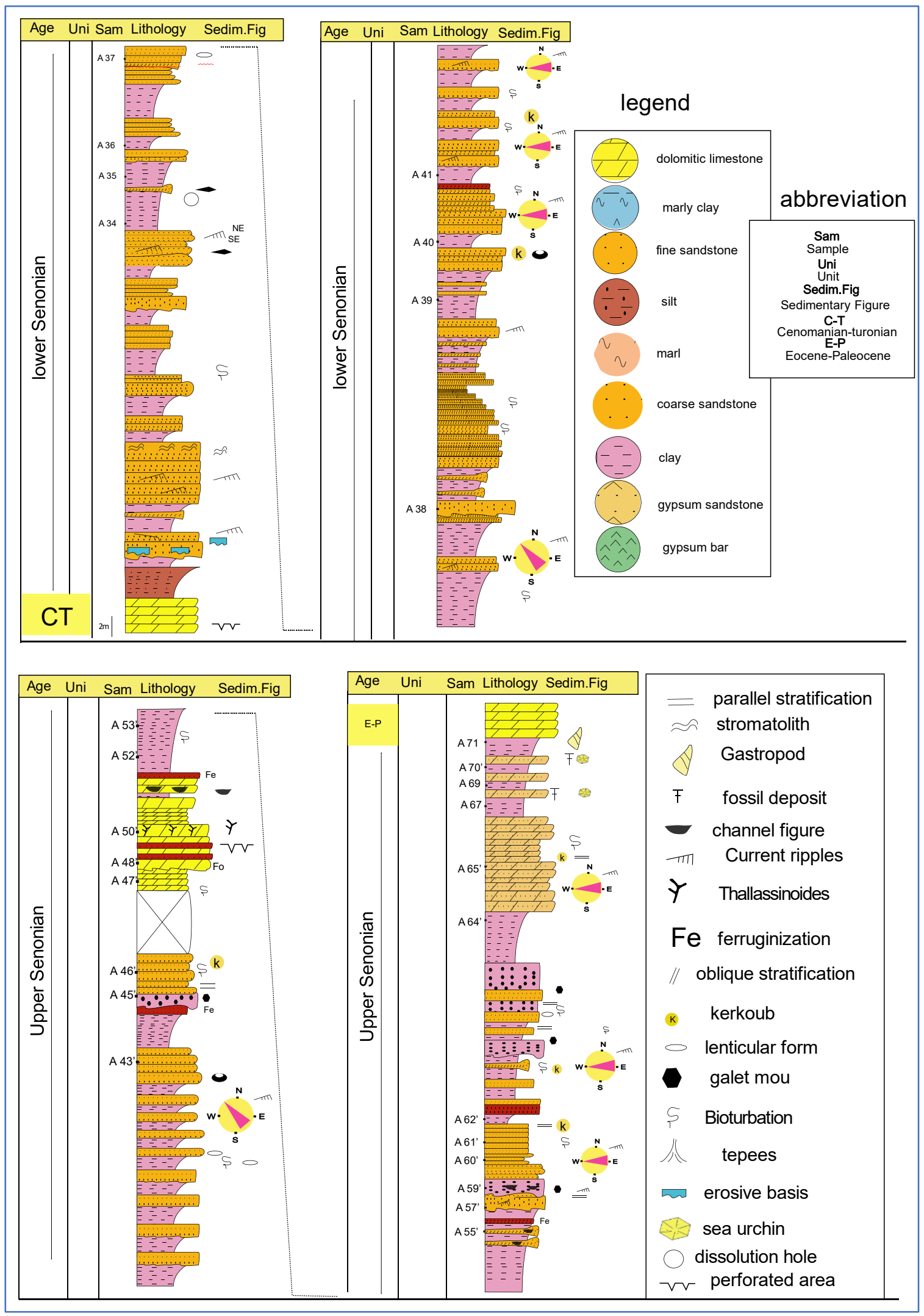

Figure.2 Stratigraphic section of detail realized, the section shows the various facies and associated sedimentary figures which illustrated the upper cretaceous of ARG N'SIDIALI OU BOURK. 


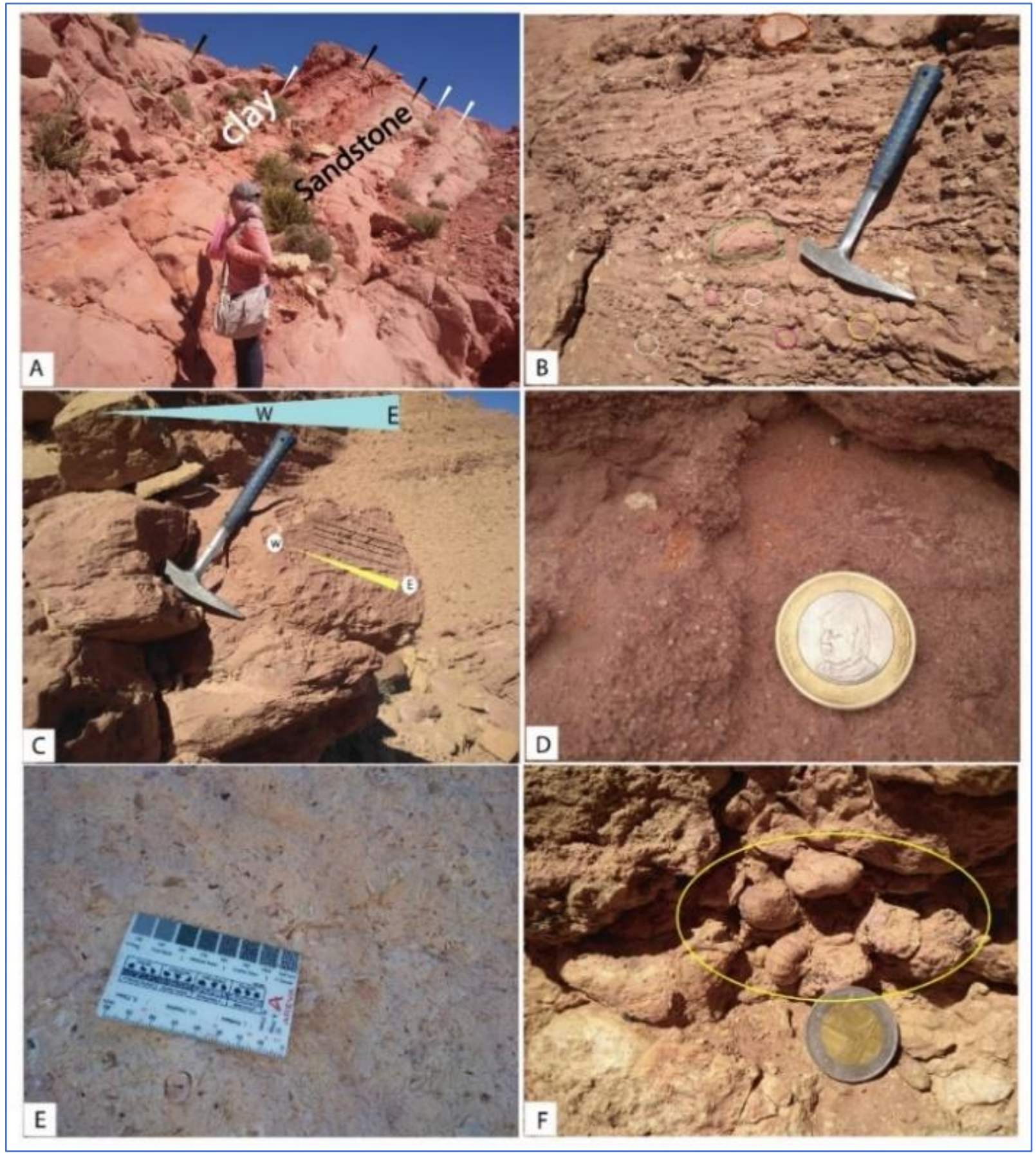

Figure.3 Photos from field mission, A: alternating fine, medium and coarse red sandstone beds with inter-beds of friable clay, B: pebbles embedded in a red clay matrix characterizing a conglomeratic pudding deposit with an erosive base, $\mathrm{C}$ : current ripples in a coarse and gross upper Senonian sandstone, D: increasing grain size in a red sandstone, E: Cenomano-Turonian surface, perforated, oxidized and fossilized, F: a deposit of fossils of ursians collected on a marl bank. 


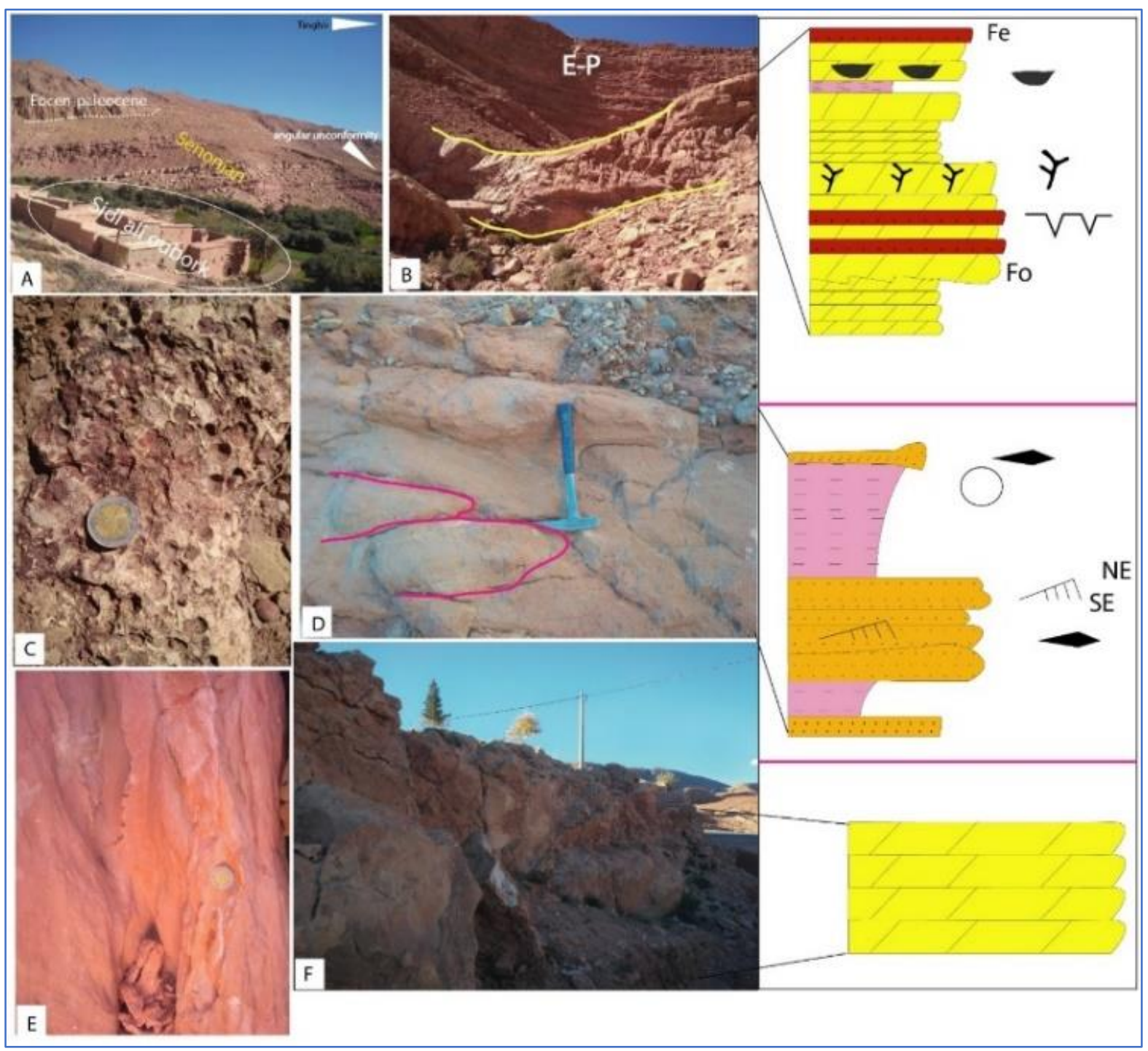

Figure.4 Photos taken during the field mission, A: panoramic view of the Senonian (red formation) of ARG N'SIDIALI OU BOURK with the Eocene-Paleocene which crowns the whole Senonian series, on the right of the photo an angular discordance is marked in the study zone, :B the Senonian metric limestone bar with on the right some schematic details, C: surface of a ferruginous sandstone evoking a sedimentary discontinuity, D: Lenticular sandstone forms, E: a marly clay with a certain bioturbation pattern, F: Cenomano-Turonian limestone bar.

\subsection{Clay analysis}

The clay mineral assemblages encountered in the ARG N'SIDIALI OU BOURK section (Figure.5) show the omnipresence of illite, kaolinit and muscovite; the presence of Illite suggests an active erosion of the hinterland. It would probably come from the superficial alteration of pre-existing phyllite minerals. Its association with kaolinite in most of the Senonian seems to indicate a fluvial contribution from the piedmont regions (Sittler et al 1964). Chlorite could suggest an erosion of emerged domains with accentuated relief. It would thus come from the ante-jurassic series rich in chlorite. However, considering the multiple factors that influence its crystalline network, a partial genesis by the smectite transformation can be envisaged. The post-cretaceous series is a potential source for the probable, which would feed the ARG N'SIDIALI OU BOURK basin with detrital elements (sources of clay assembly). These minerals result from sedimentation in a shallow, confined and calm environment of the sebkha. (Figure.5) 


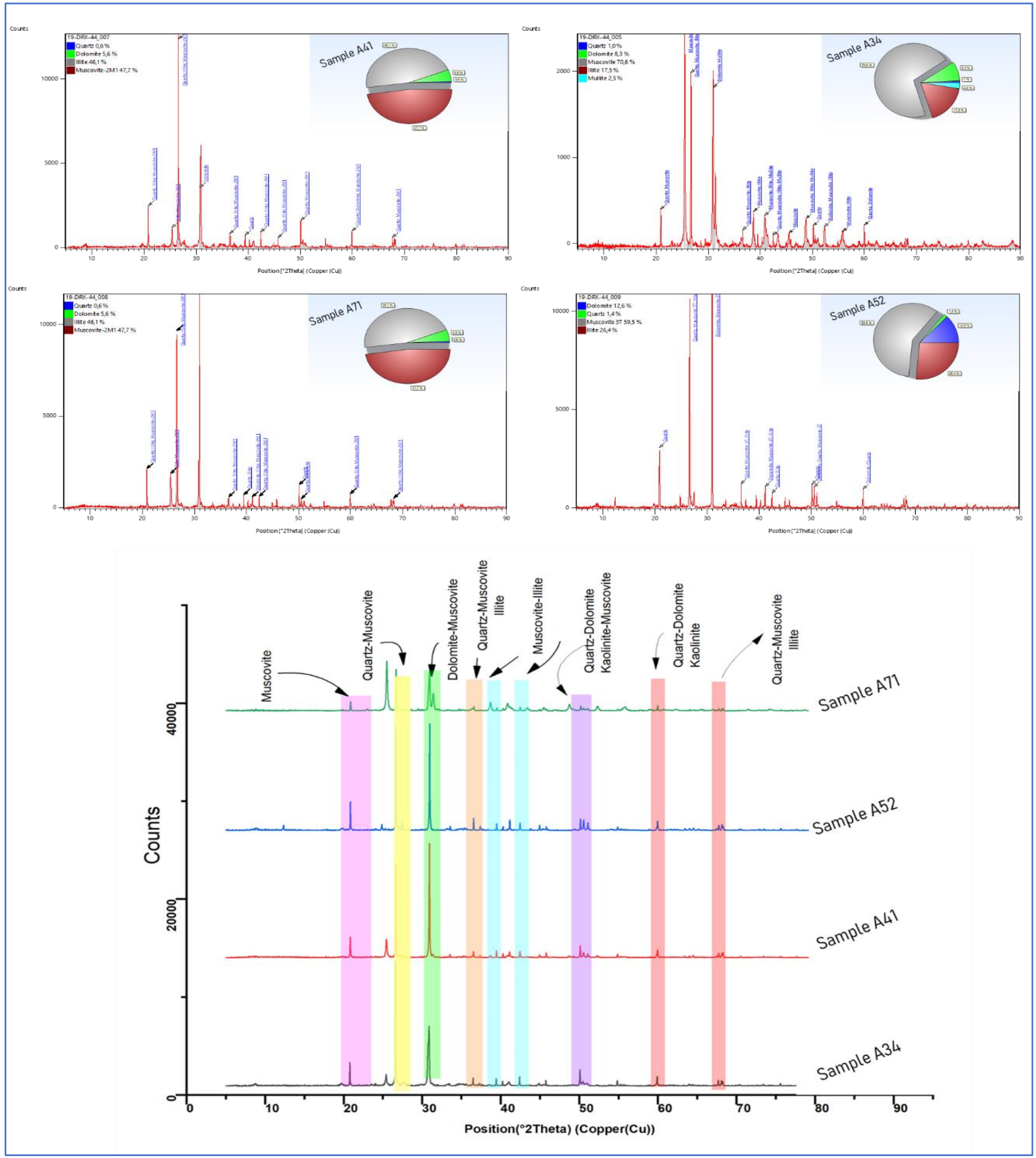

Figure.5 Variation of mineralogical assemblage in the lithostratigraphic section of ARG N'SIDIALI OU BOURK

\subsection{Exoscopic analysis}

The exoscopic study of quartz grains shows, on the one hand, the existence of several types of mechanical and chemical erosion (Fig.6), and on the other hand the presence of dissolution figures on the surface of several quartz grains, the quartz grains of ARG N'SIDIALI OR BOURK showed that these grains are transported by wind and water. These modes of transport are recognized by the presence of traces of crescent and V-shaped shocks on the surface of the grains, which then underwent an evolution in the shallow intertidal marine environment marked by the precipitation of silica resulting from the evaporation of water highly concentrated in silica and dissolution. 
The sedimentation of the limestone and dolomitic marl formation is marked by evaporitic levels in the form of banks of impure gypsum "saccharoid", of primary or fibrous gypsum of secondary origin. The presence of this type of sedimentation characterizes a laguno-continental environment. Therefore, this formation's deposits result from sedimentation in a calm, shallow and confined environment, subject to phases of emergence with variations of salinity under a hot and arid climate. The clay analyses and exoscopy confirmed that the deposition of the red formation of senonian series with its limestone intercalations was carried out in a continental-lagoon environment

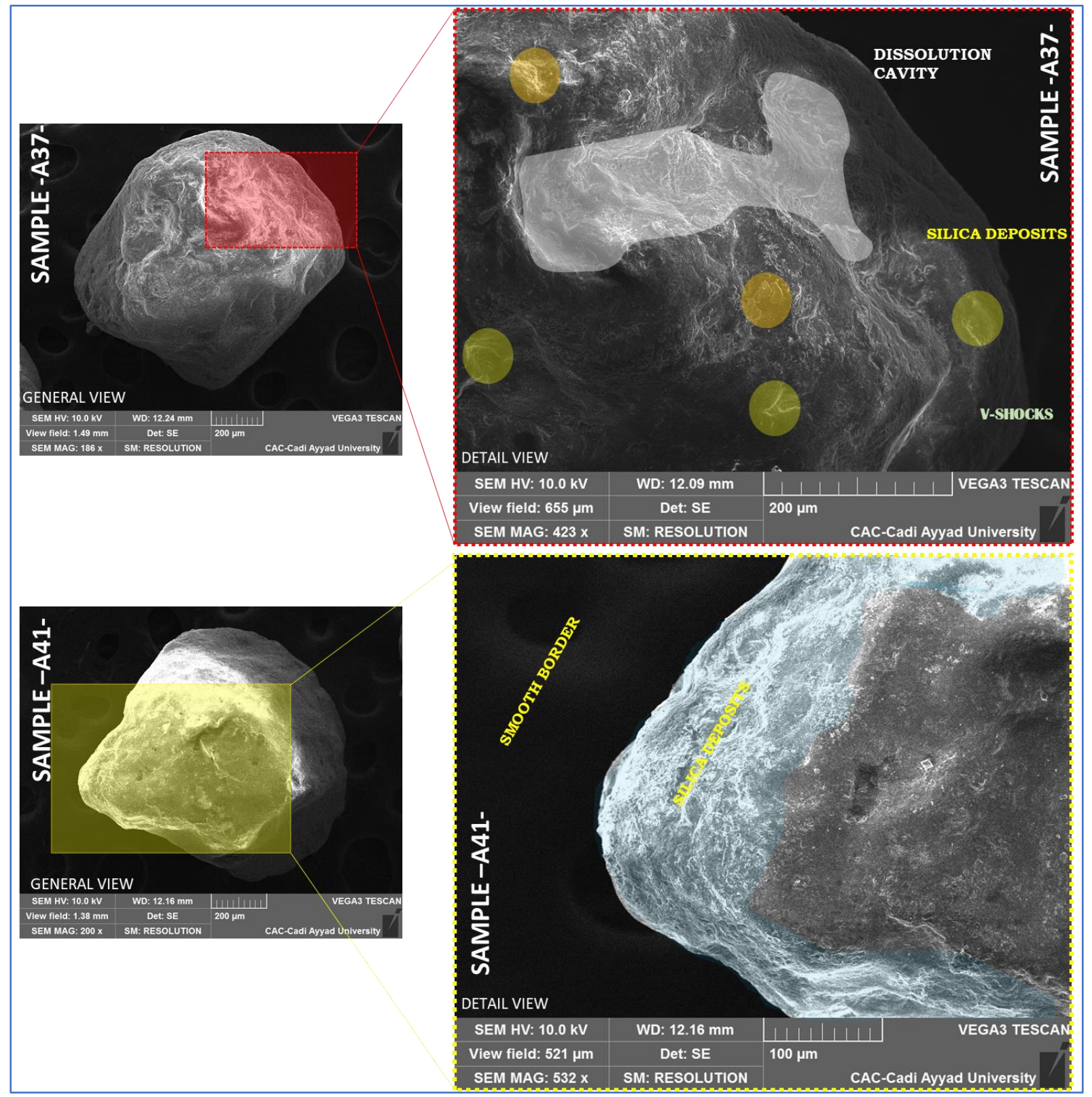

Figure.6 Pictures show a general view as well as a detailed view (different figures recorded on the quartz surface) of a quartz grain of the enchantment A37 at the top, and of the sample A41 at the bottom

\section{Conclusion}

The deposits of the Senonian series of 'ARG N'SIDI ALI OU BOURK are interpreted as resulting from sedimentation in a continental lagoon environment. It is characterised by sedimentation in the fluvial or flooded environment, with some rare marine upwelling marked by the setting of whitish sandstone bars. These sediments present intermittent terrigenous input phases, indicating the installation of a lagoon-continental environment. The sedimentological, stratigraphic and exoscopic analyses of quartz and clay allowed proposing a simplified functional diagram of the study area (figure 7). The sedimentation of the limestone and dolomitic marl formation is marked by evaporitic levels in the form of banks of impure gypsum "saccharoid", 
of primary or fibrous gypsum of secondary origin. The presence of this type of sedimentation characterizes a lagoonscontinental environment. Therefore, this formation's deposits result from sedimentation in a calm, shallow and confined environment, subject to phases of emergence with salinity variations under a hot and arid climate. The clay analyses and exoscopy confirmed that the deposition of the red formation of senonian series with its limestone intercalations was carried out in a continental lagoon environment.

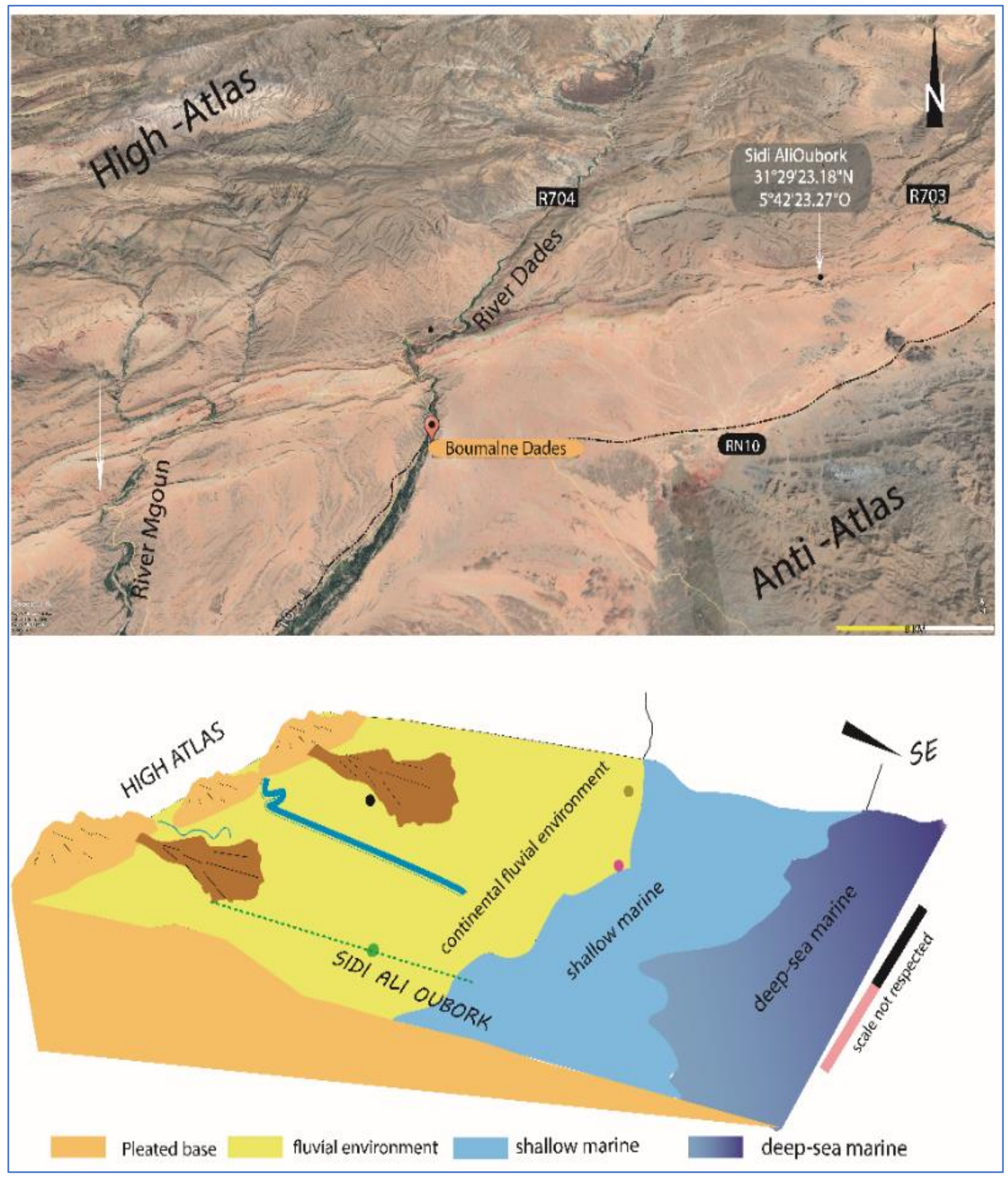

Figure.7 A simplified model for the deposit of Senonian formations in The Sidi Ali Oubork area. 


\section{Acknowledgement}

The authors of this work are very grateful to the anonymous reviewers for their valuable comments and suggestions and to the editor of the journal for a careful review of the article, which helped present and work lucidly.

\section{References}

[1] BERNIER, P. (1984). Les formations carbonatées du Kimméridgien et du Portlandien dans le Jura méridional. Stratigraphie, micropaléontologie, sédimentologie (fascicule 2). Travaux et Documents des Laboratoires de Géologie de Lyon, 92(2), 3-803.

[2] COLMENERO-HIDALGO, E., FLORES, J. A., SIERRO, F. J., BÁRCENA, M. A., LÖWEMARK, L., SCHÖNFELD, J., \& GRIMALT, J. O. (2004). Ocean surface water response to short-term climate changes revealed by coccolithophores from the Gulf of Cadiz (NE Atlantic) and Alboran Sea (W Mediterranean). Palaeogeography, Palaeoclimatology, Paleoecology, 205(3-4), 317-336.

[3] Est-Atlantique voisin. Annales de la Société Géologique du Nord, 108(1), 15-24.

[4] DURAND, M. (1978). Paléocourants et reconstitution paléogéographique. L'exemple du Buntsandstein des Vosges méridionales (Trias inférieur et moyen continental).

[5] EKDALE, A. A., \& BROMLEY, R. G. (2003). Paleoethologic interpretation of complex Thalassinoides in shallow-marine limestones, Lower Ordovician, southern Sweden. Palaeogeography, Palaeoclimatology, Palaeoecology, 192(1-4), 221-227.

[6] FREY, F. A., GREEN, D. H., \& ROY, S. D. (1978). Integrated models of basalt petrogenesis: a study of quartz tholeiites to olivine melilitites from south eastern Australia utilizing geochemical and experimental petrological data. Journal of petrology, 19(3), 463-513.

[7] HADACH, F., ALGOUTI, A., ALGOUTI, A., \& MOURABIT, Z. (2015). Example ofpaleosebkha littoral deposits of Senonian in the" basins zone" of Ait Ourir (Marrakech High Atlas, Morocco). European Scientific Journal, 11(18).

[8] GAUTHIER-LIÈVRE, L. (1957). Additions aux Nebela d'Afrique. Bull. Soc. Hist. Nat. Afr. Nord, 48, 494-523.

[9] KENNEDY, W. J., \& MACDOUGALL, J. D. S. (1969). Crustacean burrows in the Weald Clay (Lower Cretaceous) of south-eastern England and their environmental significance. Palaeontology, 12(3), 459-471.

[10] Laville, E. (1980). Tectonique et microtectonique d'une partie du versant sud du Haut Atlas marocain (boutonnière de Skoura, nappe de Toundout).

[11] LE RIBAULT L., (1977). - L'éxoscopie des quartz, Masson et W editeurs, Paris, p150.

[12] MARCELINO, V., MUSSCHE, G., \& STOOPS, G. (1999). Surface morphology of quartz grains from tropical soils and its significance for assessing soil weathering. European journal of soil science, 50(1), 1-8.

[13] MARZOQI, M., \& PASCAL, A. (2000). Séquences de dépôts et tectono-eustatisme à la limite Crétacé/Tertiaire sur la marge sud-téthysienne (Atlas de Marrakech et bassin de Ouarzazate, Maroc). Newsletters on Stratigraphy, 57-80.

[14] MATTAUER, M., TAPPONNIER, P., \& PROUST, F. (1977). Sur les mécanismes de formation des chaines intracontinentales ; l'exemple des chaines Atlasiques du Maroc. Bulletin de la Société géologique de France, 7(3), 521-526.

[15] Cavallina, C., Papini, M., Moratti, G., \& Benvenuti, M. (2018). The late Mesozoic evolution of the Central High Atlas domain (Morocco): Evidence from the paleo-drainage record of the Adrar Aglagal syncline. Sedimentary Geology, 376, 1-17.

[16] MICHARD A.D., (1976). Eléments de géologie marocaine. Notes et Mémoires du Service Géologique du Maroc, $n^{\circ} 252,408$ p.

[17] RHOADS, D. C., \& DC, R. (1974). Organism-sediment relations on the muddy sea floor.

[18] REINECK, H. E., \& SINGH, I. B. (2012). Depositional sedimentary environments: with reference to terrigenous clastics. Springer Science \& Business Media.

[19] RENAUD-MORNANT, J. (1976). Le genre Flobarts Delamare Deboutteville et Renaud-Mornant, 1965 en Méditerranée ; description de deux espèces nouvelles (Arthrotardigrada). Bulletin du Museum National histories Naturelle, Paris, Série 3e, 257, 325-333

[20] SITTLER, C., \& MILLOT, G. (1964). Les climats du Paléogène français reconstitués par les argiles néoformées et les microflores. Geologische Rundschau, 54(1), 333-343.

[21] TABUCE, R., ADNET, S., CAPPETTA, H., NOUBHANI, A., \& QUILLEVÉRÉ, F. (2005). Aznag (bassin d'Ouarzazate, Maroc), nouvelle localité à sélaciens et mammifères de l'Eocène moyen (Lutétien) d'Afrique. Bulletin de la Société géologique de France, 176(4), 381-400.

[22] WEIMER, R. J., \& HOYT, J. H. (1964). Burrows of Callianassa major Say, geologic indicators of littoral and shallow neritic environments. Journal of Paleontology, 761-767. 